\title{
Common mental disorders among medical students
}

\author{
Transtornos mentais comuns entre estudantes de medicina
}

\section{Palavras-chaves}

Transtornos mentais, estudantes de medicina, saúde mental, aprendizagem.

\section{Key-words}

Mental disorders, medical students, mental health, learning.
Alessandro de Moura Almeida', Tiana Mascarenhas Godinho', Almir Galvão Vieira Bitencourt', Marcelo Santos Teles', André Sampaio Silva', Dayanne Costa Fonseca', Daniel Batista Valente Barbosa', Patrícia Santos Oliveira', Eduardo Costa-Matos', Cíntia Rocha e Rocha', Alan Miranda Soares', Bárbara Abade?', Irismar Reis de Oliveira'

\section{RESUMO}

Objetivo: Transtornos mentais comuns (TMC) possuem alto impacto nos relacionamentos interpessoais e na qualidade de vida, sendo potenciais substratos para o desenvolvimento de transtornos mais graves. Estudantes de medicina vêm sendo apresentados como população de risco para o desenvolvimento de TMC. O objetivo deste estudo é estimar a freqüência de TMC em acadêmicos de medicina da Universidade Federal da Bahia e identificar fatores relacionados. Métodos: Realizou-se estudo transversal entre uma amostra de estudantes de medicina. A identificação dos TMC foi feita por meio do 20-item Self-Report Questionnaire. Resultados: Foram avaliados 223 estudantes. A prevalência de TMC foi de 29,6\%, sendo independentemente associada a alterações do padrão do sono, não possuir transporte próprio, não trabalhar e não realizar exercício físico. Conclusões: Estes dados demonstram uma elevada prevalência de TMC na amostra pesquisada e são importantes para subsidiar ações de prevenção de transtornos mentais entre futuros médicos e reflexões sobre o modelo curricular vigente nas escolas médicas.

\section{ABSTRACT}

Objective: Common mental disorders (CMD) have a high impact on interpersonal relationships and quality of life and are potential underlying causes for the development of more serious disorders. Medical students have been indicated as a risk population for the development of CMD. The aim of this study was to determine the frequency of CMD in undergraduate medical students and to identify related factors. Methods: A cross-sectional study was performed in a sample population of medical students. CMD was identified according to the 20-item Self-Report Questionnaire. Results: Two hundred and twenty-three students completed the questionnaire. The overall prevalence of CMD was $29.6 \%$ and its presence was independently associated with sleep disorders, not owning a car, not working and sedentary lifestyle. Conclusions: These findings indicate a high prevalence of CMD in the sample studied and are important for supporting actions to prevent mental disorders in future doctors and for reflecting on the curricula currently in use in medical schools.

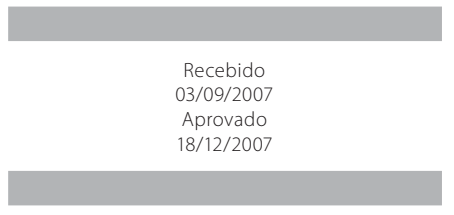

1 Departamento de Neuropsiquiatria - Escola de Medicina da Bahia - Universidade Federal da Bahia.

Endereço para correspondência: Alessandro de Moura Almeida.

Rua Nossa Senhora de Brotas, 107. Fauna - 703. Brotas - 40285-170. Salvador, BA.

E-mail: alessandrodemoura@yahoo.com.br 


\section{INTRODUCTION}

Common mental disorders (CMD) are usually characterized as disorders that, although initially requiring no psychiatric treatment, later prove to have great socioeconomic impact. Moreover, there are potential underlying causes for the development of more serious mental disorders. Common mental disorders are related to somatoform disorders and to anxiety and depression (Mari and Jorge, 1997). Characteristic symptoms include insomnia, fatigue, irritability, forgetfulness, difficulty in concentrating and somatic complaints, though psychotic, personality-related disorders and chemical dependence are not involved (Goldberg and Huxley, 1992).

In populations of industrialized nations its prevalence varies from 7\% to 30\% (Harding et al., 1980). In Brazil, a study performed in 1994 revealed that $22.7 \%$ of the adult urban population of Pelotas, Rio Grande do Sul, had CMD (Ludemir and Melo-Filho, 2002). Since these disorders are frequent in the community, they represent high social and economical costs, being responsible for a significant number of lost workdays, and an increased demand for health services (Harding et al., 1980).

It has been demonstrated that the admission of university students into the academic environment consists of a multiple process that involves not only external factors such as the influence of the social environment and of academic norms, but also internal factors that are related to the ability of the individual to deal with diverse situations, psychosomatic physical reactions and mood states (Polydoro et al., 2001). Medical School, itself, is a stressful environment. The course peculiarities that expose the student to many sources of tension from admission into the university include the competitiveness of the selection process, the excessive study load, personal striving and the professors' demand for excellence, lack of leisure time and contact with death, in addition to other factors (Firth, 1986). Various studies worldwide have demonstrated high rates of psychic disorders in this type of population (Rosal et al., 1997; Dahlin et al., 2005; Facundes and Ludermir, 2005). In a african study, it was demonstrated that $64.5 \%$ of first-semester medical students presented some degree of stress or depression, with $11 \%$ demonstrating very high levels of stress (Vaz et al., 1998). Such situations of stress may lead to mental disorders and may have a negative impact on cognitive function and learning (Saipanish, 2003). As such, this is a population that is recognizably immersed in risk situations, reflecting a need for more detailed studies. The purpose of the present study was to determine the frequency of common mental disorders in students at the School of Medicine of the Federal University of Bahia, and to identify factors involved in the social, economic and academic life of these students that could be related to the presence of CMD.

\section{METHOD}

A cross-sectional study was carried out between June and July, 2005, at the end of the first school semester of that year. Students in the eighth semester of medical school delivered self-administered, anonymous questionnaires to male and female students enrolled in the $2^{\text {nd }}, 4^{\text {th }}, 6^{\text {th }}$ and $8^{\text {th }}$ semesters and in the final two years of Medical School (from the $9^{\text {th }}$ to the $12^{\text {th }}$ semesters) at the Federal University of Bahia (FAMEB/ UFBa). Eight hundred and eighty-eight students were enrolled in the medical school and 556 were eligible for enrolment in the study. A sample of half the eligible individuals (278) was selected from students attending theoretical or practical classes during the period of the study. Two hundred and twentyfive students (response rate, 80.9\%) agreed to participate in the study, completing and returning the questionnaire. The questionnaire requested information on: identification (age, gender, school semester, marital status, skin color); life habits (diet, physical exercise, use of tobacco, alcohol or other psychoactive drugs, sleep patterns); medical history (previous illnesses and medical treatments), use of medication; socioeconomic conditions (monthly income, hours of work per week, whether the participant owned his/her own home, number of people living in the house, whether the student had his/her own car); and any stressful life events in the 12 months prior to filling out the questionnaire (serious illness, death of near relatives, hospitalization, separation/divorce, obliged to move away from home, grave financial problems, physical violence, assault or robbery). Monthly income was expressed as the number of minimum wages, one minimum monthly wage being $\mathrm{R} \$ 300$ (approximately 140 dollars).

CMD was identified according to the results of the 20item Self-Report Questionnaire (SRQ-20), initially developed at the beginning of the 1980's to screen psychiatric disorders in primary health centers (Harding et al., 1980) and validated in Brazil in 1986 (Mari and Williams, 1986). This instrument is composed of 20 questions, with dichotomized responses (yes and no) (yes and no), to which are attributed a score equivalent to 1 (one) for each question with an affirmative response, resulting in a total final score that ranged from 0 to 20. The individuals who participated in the study were divided, by gender, into two groups (suspect and non-suspect), according to scores from the SRQ-20: the cut-off used among the male individuals was established as greater or equal to six points and, among the female individuals, as greater or equal to eight points. These cut-off points demonstrated sensitivity and specificity of $89 \%$ and $81 \%$, respectively, for males and $86 \%$ and $77 \%$ for females (Mari and Williams, 1986).

The results were analyzed using the SPSS (Statistical Package for the Social Sciences), version 9.0 (SPSS Inc. Chicago, Illinois). Descriptive analysis of the variables was carried out, making the appropriate correlations. Student T-test and the 
ANOVA test were used to analyze continuous variables according to groups and the Chi-square or Fisher exact test was used to analyze the proportions, In addition, Spearman's correlation was used to quantify the association between two continuous variables. Logistic regression was performed to identify variables associated with a positive score in the SRQ-20, using Backward Stepwise method. The following variables were tested in the multivariate model: gender, age, semester of study, skin color, marital status, whether student has his/her own home, family income, extracurricular activities, employment, main form of transportation, performance of physical exercise, reservation of weekly time for leisure, whether subject has any dietary restrictions, tobacco consumption, alcoholism, use of psychoactive substances, use of regular medication, whether undergoing or have undergone psychotherapy, sleep patterns and whether subject has been submitted to any stressful event in the last 12 months. The tobacco variable was excluded from the model as a result of the sample size. The type I error was considered to be $5 \%$ for all analysis. This study was approved by the Institutional Review Board of Federal University of Bahia. All of the participants in the study have signed a written informed consent regarding their participation.

\section{RESULTS}

Two-hundred and twenty-five medical students were evaluated. The questionnaires of two students were excluded because they failed to answer any of the questions in the evaluation instrument (SRQ-20); therefore, the responses of 223 students were analyzed. The demographic and socioeconomic characteristics of participants are shown in Table 1.

According to the previously established cut-off, the prevalence of common mental disorders in this population was $29.6 \%$ ( $n=66)$. The average score obtained was $4.87 \pm 3.98$ (median: 4.00; mode: 1; range: 0-16). No significant difference in the score or in the prevalence of CMD was observed as the students progressed through medical school (Table 2).

The majority of the individuals $(76.0 \%, n=165)$ performed extracurricular academic activities, with almost half of them (41.2\%, $n=68)$ receiving remuneration for these activities. Only 28 (12.6\%) students had a job unrelated to their academic activities. Eighty-six individuals (38.7\%) practiced regular physical exercise, while 43 (19.4\%) declared that they had no time for leisure activities during the week. Tobacco and alcohol use were reported by $4.0 \%(n=9)$ and $56.1 \%(n=125)$, respectively. Only eight (3.6\%) students reported the use of other psychoactive substances. Regular use of medication was reported by $24.8 \%(n=55)$. Twenty-three $(10.4 \%)$ students were undergoing or had undergone some type of psychotherapy. The relationship between the presence of these variables and a positive score for CMD is shown in Table 3 .
Table 1. Demographic and socio-economic characteristics of the studied population.

\begin{tabular}{|c|c|c|}
\hline Characterístics & $\mathrm{N}$ & $\%$ \\
\hline \multicolumn{3}{|l|}{ Gender* } \\
\hline Male & 112 & 50.2 \\
\hline Female & 108 & 48.4 \\
\hline \multicolumn{3}{|l|}{ Age } \\
\hline Mean $( \pm S D)$ & $22.0( \pm 1.9)$ & \\
\hline Median & 22 & \\
\hline Range & $18 \quad 30$ & \\
\hline \multicolumn{3}{|l|}{ Academic semester** } \\
\hline Second & 45 & 20.2 \\
\hline Fourth & 43 & 19.3 \\
\hline Sixth & 44 & 19.7 \\
\hline Eighth & 42 & 18.8 \\
\hline Ninth to twelfth & 47 & 21.1 \\
\hline \multicolumn{3}{|l|}{ Skin color* } \\
\hline White & 100 & 44.8 \\
\hline Mulatto & 112 & 50.2 \\
\hline Black & 8 & 3.6 \\
\hline \multicolumn{3}{|l|}{ Marital status*** } \\
\hline Single & 211 & 94.6 \\
\hline Married & 2 & 0.9 \\
\hline Widow(er)/separated & 0 & 0 \\
\hline \multicolumn{3}{|l|}{ With whom student lives" } \\
\hline Alone & 18 & 8.1 \\
\hline Family & 173 & 77.6 \\
\hline Friends & 21 & 9.4 \\
\hline Relatives/boy(girl)friend & 10 & 4.5 \\
\hline \multicolumn{3}{|l|}{ Type of residence* } \\
\hline Own home & 153 & 68.6 \\
\hline Rented home & 57 & 25.6 \\
\hline Lodging provided by others & 5 & 2.2 \\
\hline University dormitory/boardinghouse & 5 & 2.2 \\
\hline \multicolumn{3}{|l|}{ Type of transportation most used ${ }^{\# \#}$} \\
\hline Own car & 122 & 54.7 \\
\hline Get a ride & 18 & 8.1 \\
\hline Bus & 75 & 33.6 \\
\hline 0thers (motorcycle, walks) & 3 & 1.4 \\
\hline \multicolumn{3}{|l|}{ Monthly family income (in minimum wages) } \\
\hline From 0 to $10 \mathrm{~min}$. wages & 46 & 20.6 \\
\hline From 10 to $20 \mathrm{~min}$. wages & 74 & 33.2 \\
\hline More than 20 min. wages & 92 & 41.3 \\
\hline
\end{tabular}

Missing values: ${ }^{*} 3 ; *{ }^{*} 2 ; * * * 10 ; 1 ; *$; $; * 11$

Table 2. Total Score and Prevalence of Common Mental Disorders obtained on SRQ-20 according to Semester Studied

\begin{tabular}{lcc}
\hline Semester of medical course & Total score $($ average \pm SD) & Prevalence $(\%)^{2}$ \\
\hline Second & $5.71 \pm 4.29$ & 40.0 \\
Fourth & $5.09 \pm 4.09$ & 30.2 \\
Sixth & $3.93 \pm 3.13$ & 20.5 \\
Eighth & $5.12 \pm 4.48$ & 33.3 \\
Ninth to twelfth & $4.55 \pm 3.83$ & 25.5 \\
\hline
\end{tabular}

SD: standard deviation

'ANOVA: $p$-value $=0.405$

2Pearson Chi-Square: $\mathrm{p}$-value $=0.316$

More than half of the students $(53.8 \%, n=120)$ reported a normal sleep pattern. However, the following disorders were observed in the sleep patterns of the remaining individuals: daytime sleepiness, $27.8 \%$ ( $n=62)$; difficulty in falling asleep, 
Table 3. Univariate Analysis between Factors Studied and CMD

\begin{tabular}{lrrr}
\hline Factors related to CMD & Non-suspect & Suspect & p-value \\
\hline Female gender & $45.8 \%$ & $56.9 \%$ & 0.132 \\
Age, in years & $22.1 \pm 1.9$ & $22.0 \pm 2.0$ & 0.840 \\
Skin color (white) & $47.7 \%$ & $40.9 \%$ & 0.375 \\
Marital status (single) & $98.7 \%$ & $100 \%$ & 1.000 \\
Lives in his/her own home & $71.6 \%$ & $64.6 \%$ & 0.304 \\
Monthly income above 10 minimum wages & $80.4 \%$ & $73.4 \%$ & 0.258 \\
Perform extracurricular activities & $77.0 \%$ & $73.8 \%$ & 0.621 \\
Do not work & $84.6 \%$ & $93.9 \%$ & 0.075 \\
Do not practice regular physical activity & $55.1 \%$ & $75.8 \%$ & 0.004 \\
Do not reserve time weekly for leisure & $14.1 \%$ & $31.8 \%$ & 0.002 \\
Have some dietary restrictions & $7.0 \%$ & $9.1 \%$ & 0.592 \\
Tobacco consumption & $5.7 \%$ & $0 \%$ & 0.061 \\
Alcohol use & $58.0 \%$ & $51.5 \%$ & 0.376 \\
Regular use of medication & $22.4 \%$ & $30.3 \%$ & 0.215 \\
Have already undergone psychotherapy & $7.6 \%$ & $16.9 \%$ & 0.039 \\
Have some alteration in sleep pattern & $34.4 \%$ & $74.2 \%$ & $<0.001$ \\
Do not have own transportation & $35.5 \%$ & $63.6 \%$ & $<0.001$ \\
\hline
\end{tabular}

$16.6 \%(n=37)$; premature awakening, $8.1 \%(n=18)$; and difficulty in staying asleep, $5.8 \%(n=13)$. The presence of some sleep pattern disorder was associated with a greater prevalence of CMD when compared to the group with a normal sleep pattern (47.6\% x 14.2\%, respectively; $\mathrm{p}<0.001)$.

A total of 119 students (53.4\%) reported having experienced stressful life events in the previous 12 months. Although the presence of these events was not associated with a greater prevalence of $C M D$, the increase in the number of events was correlated with a higher score $(r=0,188 ; p=0.041)$.

In the multivariate analysis, it was demonstrated association between a positive score on the SRQ and alteration in the sleep pattern, sedentary life style, not working and not having a car (Table 4). The condition of undergoing or having undergone psychotherapy, although this was included among the variables selected in the multivariate analysis, showed no significant association with the presence of common mental disorders (OR: 2.082; 95\% Cl: 0.749 - 5.784).

Table 4. Factors Independently Associated with Common Mental Disorders

\begin{tabular}{lcccr}
\hline Variable & Beta & SE* $^{*}$ & Odds-ratio (Cl95\%) & p-value \\
\hline Intercept & -4.113 & 0.782 & 0.016 & $<0.001$ \\
Sleep pattern disorder & 1.901 & 0.369 & $6.690(3.244-13.797)$ & $<0.001$ \\
Sedentary life style & 0.769 & 0.377 & $2.159(1.030-4.522)$ & 0.041 \\
Do not work & 1.266 & 0.641 & $3.546(1.009-12.455)$ & 0.048 \\
Do not own a car & 1.361 & 0.366 & $3.898(1.904-7.982)$ & $<0.001$ \\
\hline *EE: Standard error & & & &
\end{tabular}

*SE: Standard error

\section{DISCUSSION}

The prevalence of CMD in the sample studied was 29.6\%. This value could be considered high, considering the values in studies conducted in industrialized nations, that vary from 7\% to 30\% (Goldberg and Huxley, 1992), because the rate found in the present study is one of the highest cited. Other studies carried out in Brazil have reported a lower prevalence of CMD in the following professional categories: teachers in the private school network (18.7\%) (Araújo et al., 2003), subway workers (25.8\%) (Jardim et al., 1996) and hospital workers (20.9\%) (Pitta, 1990), as well as among adolescents (8\%) (Feijó et al., 1997). As a risk population for the development of mental disorders (Rosal et al.,1997; Dahlin et al., 2005), the values found among Brazilian medical students are extremely variable. Similar rates to the general population were described among others Brazilian students in two cities in South Brazil (19.0\% and 22.19\%) (Benvegnu et al., 1996; Hidalgo et al., 2001). However, more elevated values were also recorded in Brazilian universities (31.7\% to 44.7\%) (Facundes and Ludermir, 2005; Benvegnu et al., 1996; Lima et al., 2006) and in a prior study that involved ninety medical students of this same School of Medicine, but using a different diagnostic instrument (37.8\%) (Azi, 2002). High rates of CMD (33.3\% and 31.8\%) have also been found in Brazilian dental and nursing students, respectively (Facundes and Ludermir, 2005), as well as in college professors in another city in the same state (29\%) (Araújo et al., 2003).

Similar rate was found among brazilian doctors (26.0\%) (Nascimento-Sobrinho et al., 2006), which could suggest that the same factors influencing the development of mental disorders among medical students may be present in the professional life of the subject, such as the contact with death and suffering (Firth, 1986). Among the problems potentially associated with working in the medical field, Nascimento-Sobrinho et al. (2006) emphasize the excess workload, especially the regime of nights, weekends and holidays on-duty to insure emergency medical services, which could be equivalent to the long hours of study encouraged by the competitive environment in medical schools (Yiu, 2005). Although medical students tend to have high personal standards, which gives them an advantage in what is a highly competitive profession, this is associated to perfectionism that leads to search for high academic performance. Such factors could act as stress agents within this process. In a study carried out in Sweden, $77.9 \%$ of first-year medical students affirmed that their studies controlled their lives, with little time left over for other activities (Dahlin et al., 2005). Furthermore, $70.8 \%$ of this population mentioned a perceived lack of encouragement from professors in this respect (Dahlin et al., 2005). Nogueira-Martins et al. (2004) points out that some of the student's problems could be overcome with the help of a more experienced mentor, who could offer students support by creating a work and learning environment that would encourage communication between professors and students.

A systematic review of 40 articles on North American medical students psychological distress suggested a high prevalence of depression and anxiety in this population, 
with higher levels of overall psychological distress compared to the general population (Dyrbye et al., 2006b). In that review, the authors found that, although distress among medical students has been recognized for decades, limited data are available on causes of this problem, its consequences and solutions (Dyrbye et al., 2006b).

The moment during medical school when the risk of developing mental disorders is greater remains controversial. This is due to the different characteristics of each medical school and its students and professors. Among students of the University of Massachusetts, for example, there was an increase in the levels of stress and depression among second and fourth-year students, while in the United Kingdom and Thailand greater levels of mental disorders were recorded among first and third year students, respectively (Rosal et al., 1997; Saipanish, 2003; Guthrie et al., 1998). No difference was found between the semesters in relation to the presence of common mental disorders. Similar results have also been mentioned by other studies, including those involving Brazilian students (Facundes and Ludermir, 2005; Benvegnu et al., 1996; Lima et al., 2006). This could indicate that both in the phase of admission to medical school and in the process of adaptation to academic environment, the characteristics of the teaching-learning process differ, and a specific set of factors with a negative influence on the mental health of the students may occur at each level of this process (Facundes and Ludermir, 2005). However, these conclusions include important limitations inherent to the design of the study. It is possible that a longitudinal inventory of psychiatric morbidity is more capable of estimating the occurrence of diagnoses made throughout the life of students and the influence of the medical curriculum on them, contributing toward the identification of potential risk factors for the development of mental disorders in this population. In addition, another limitation is that only medical students who were in academic activities have answered the questionnaire and the results could be a little different, because common mental disease may be responsible for work days loss (Harding et al., 1980). However, the majority of missing samples referred to students in the final two years of medical school and this population has particular characteristics, such as a greater number of practical activities, a closer relationship with preceptors, and a less intense study workload for theoretical exams. Nevertheless, no significant differences were found between this subgroup and the others.

Some other factors have been related to the increased prevalence of CMD: demographic characteristics (gender, age and marital status); life and work conditions (poor upbringing, precarious living conditions, low income, unemployment and informal employment) and vital stress-generating life events (Ludermir and Melo-Filho, 2002; Lima et al., 1996). In the present study, no difference was found in the prevalence of mental disorders in relation to gender, skin color or marital status, although CMD was more frequent among women and non-white individuals. In relation to marital status, the majority (94.6\%) of the individuals in the sample was single; therefore, a possible correlation between marital status and mental disorder was limited due to sample size. In terms of life and work conditions, not exercising, not working and not having their own car were factors independently associated with the presence of mental disorders. Lima et al. carried out a survey in a medical school in the southeast of Brazil and showed that CMD was associated with difficulty in making friends, poor self-evaluation of academic performance, thoughts of dropping out of medical school and a perceived lack of emotional support (Lima et al., 2006). This higher prevalence of CMD and its risk factors may be explained because most students (98\%) did not live with their families.

In a population from Northeast of Brazil (Zona da Mata), Costa and Ludermir (2005) demonstrated a prevalence of CMD of $36.0 \%$, which was positively associated with poorer education level, not working and lower monthly income. Although such findings are similar to those of our study, the interpretation may be totally different due to the characteristics of each population. In the population evaluated in the study carried out by Costa and Ludermir (2005), the fact of not working may reflect the lack of socioeconomic support experienced by this community while, among medical students, it may be related to not performing other activities unconnected with the medical field that could keep the student away from the competitive and stressful environment of the medical school. The same logic may be used to explain the better mental health of individuals who perform regular physical activities, beyond the beneficial effect of exercise in improving the overall mental health of the individuals (Fox, 1999). However, in the area of social issues, since most of those interviewed have a reasonable monthly income (more than 10 minimum wages), the fact that the student does not own a car may distinguish those with fewer financial resources. Although previous studies have shown no association between medical students socioeconomic condition and development of CMD (Lima et al., 2006), these individuals may face certain difficulties during their academic life, since part of the curriculum is sometimes given in locations other than the medical school itself, and this may cause transportation problems for students without a car.

Recently, Dyrbye et al. (2006a) showed that the number of negative personal life events in the last 12 months correlated with the risk of burnout among medical students, a measure of professional distress. In the present study, the number of stress factors in the previous 12 months was significantly correlated to a higher score in the (SRQ-20) instrument, although there was no change in the prevalence of CMD in the 
group that had a stress factor. It would appear that 12 months may be too short an evaluation time for determining adverse mental conditions or that this period was able to indicate only events that contribute towards but do not determine the presence of mental disorders. Unlike these events, the presence of special situations during childhood and adolescence, such as illnesses that affect social interaction, difficulty in making friends or relating to authority and family figures, failing grades or even lack of interest in affective relationships, seems to be a factor that influences the mental health of university students (Facundes and Ludermir, 2005).

Reports in the literature describe the occurrence of abnormal sleep patterns among some risk populations, including medical students (Hidalgo et al., 2001; Rodrigues et al., 2002). It was observed that almost half the individuals studied (46.2\%) reported some degree of abnormal sleep patterns. Lower percentages have been reported for students in other regions of Brazilian, Rio Grande do Sul (28.15\%) (Hidalgo et al., 2001) and Federal District (39.5\%) (Rodrigues et al., 2002). The importance given to abnormal sleep patterns as a public health problem has been growing in recent years. It has been shown, for example, that $12 \%$ of the American population is affected by excessive daytime sleepiness (Roth and Roehrs, 1996). This has a significant social impact in terms of direct and indirect costs, since it increases expenses related to diagnostic exams, treatment and medical fees, as well as diminishing productivity on the job and hampering academic performance (Rodrigues et al., 2002; Ford and Kamerow, 1989).

Although the hypothesis that increased duration of sleep directly improves quality of life is controversial (Briones et al., 1996), in the current study the presence of sleep pattern disorders was independently associated with the presence of CMD, as previously mentioned by other studies (Ford and Kamerow, 1989). It has been suggested that insomnia may be an early warning of psychiatric disorders such as depression, anxiety and alcohol abuse (Ford and Kamerow, 1989). This relationship has also been shown previously among students at another Brazilian university, using the same evaluation instrument. The prevalence of common mental disorders was lower than that found in our sample (22.19\%) (Hidalgo et al., 2001). The frequency of difficulty in falling asleep (17.22\%) and of staying asleep (9.6\%) was similar in both studies, although premature awakening was more frequent among students in the above-mentioned study (15.23\%) (Hidalgo et al., 2001). A high prevalence of difficulty in falling asleep has been observed in many cultures and may be related to the habit of going to bed later, which may be a symptom of anxiety or depression, or even a premature symptom of any mental disorder (Hidalgo et al., 2001). Difficulty in staying asleep does not necessarily result in shorter sleep time, but in fragmented sleep, with this fragmentation often resulting in mood swings and a drop in performance (Bonett, 1985). The frequency of daytime sleepiness in our study was also lower than that registered by Rodrigues et al. (2002) (39.5\%). In that study, the authors showed that students with daytime sleepiness had poorer academic performance compared to others (Rodrigues et al., 2002). Although there is a strong relationship between the presence of sleep pattern disorders and the presence of psychiatric morbidities, as previously reported, the methodological design of the majority of the studies performed, including the present study, has some limitations to verifying the direction of the causality.

\section{CONCLUSION}

The results presented in this study offer an important panorama of the mental conditions of these medical students, revealing the high prevalence of common mental disorders and identifying factors associated with these disorders. Moreover, these findings may serve as a stimulus for future studies designed to identify causal effects among the associated factors, and may serve in the reformulation not only of the curricula currently in use in our universities, but also the teaching/learning process, to ensure that medical school does not exert any negative effect on the mental health of future health professionals.

\section{ACKNOWLEDGMENTS}

Our thanks to Annibal Muniz Silvany Neto, for his contribution in the statistical analysis.

\section{REFERENCES}

Araújo TM, Reis EJFB, Kawalkievicz C, Silvany Neto AM, Delcor NS, Paranhos I, et al.. Saúde e trabalho docente: dando visibilidade aos processos de desgaste e adoecimento a partir da construção de uma rede de produção coletiva. Educação em Revista, 37: 183-212, 2003.

Azi LA. Transtornos mentais entre estudantes de medicina [Dissertation]. Salvador: Faculdade de Medicina, Universidade Federal da Bahia; 2002.

Benvegnu LA, Deitos F, Copette FR. Problemas psiquiátricos menores em estudantes de Medicina da Universidade Federal de Santa Maria, RS, Brasil. Rev Psiquiatr Rio Gd Sul, 18: 229-33, 1996.

Bonett MH. The effect of sleep disruption on performance, sleep and mood. Sleep, 8:11-9, 1985.

Briones B, Adams N, Strauss M, Rosenberg C, Whalen C, Carskadon M, et al. Relationship between sleepiness and general health status. Sleep, 19: 583-8, 1996

Costa AG, Ludermir AB. Common mental disorders and social support in a rural community in Zona da Mata, Pernambuco State, Brazil. Cad Saúde Pública, 21: 73-9, 2005.

Dahlin $\mathrm{M}$, Joneborg N, Runeson B. Stress and depression among medical students: a crosssectional study. Med Educ, 39: 594-604, 2005.

Dyrbye LN, Thomas MR, Huntington JL, Lawson KL, Novotny PJ, Sloan JA, et al. Personal life events and medical student burnout: a multicenter study. Acad Med, 81: 374-84, 2006. (a) 
Dyrbye LN, Thomas MR, Shanafelt TD. Systematic review of depression, anxiety, and other indicators of psychological distress among U.S. and Canadian medical students. Acad Med, 81: 354-73, 2006. (b)

Facundes VLD, Ludermir AB. Common mental disorders among health care students. Rev Bras Psiquiatr, 27: 194-200, 2005

Feijó RB, Saueressig M, Salazar C, Chaves ML. Mental health screening by self-report questionnaire among community adolescents in southern Brazil. J Adolesc Health, 20: 232-7, 1997.

Firth J. Levels and sources of stress in medical students. Br Med J, 292: 1177-80, 1986.

Ford DE, Kamerow DB. Epidemiology study of sleep disturbances and psychiatric disorders: an opportunity for prevention? JAMA, 62: 1479-84, 1989.

Fox KR. The influence of physical activity on mental well-being. Public Health Nutr, 2: 411-8, 1999.

Goldberg D, Huxley P. Commom mental disorders: a bio-social model. London: Tavistock; 1992.

Guthrie E, Black D, Bagalkote H, Sahw C, Campbell M, Creed F. Psychological stress and burnout in medical students: a 5-year prospective longitudinal study. J R Soc Méd, 91: 237-243, 1998.

Harding TW, Arango MV, Baltazar J, Climent CE, Ibrahim HHA, Ladrido-Inacio L, et al. Menta disorders in primary health care: a study of the frequency and diagnosis in four developing countries. Psychol Méd, 10: 231-41, 1980

Hidalgo MPL, Ponte TS, Carvalho CG, Pedrotti MR, Nunes PV, Souza CM, et al. Association between mental health screening by Self-Report Questionnaire and insomnia in medical students. Arq Neuropsiquiatr, 59: 180-5, 2001.

Jardim RS, Perecmanis L, Silva Filho JE. Processo de trabalho e sofrimento psíquico: 0 caso dos pilotos de metrô do Rio de Janeiro - II. J Bras Psiquiatr, 45: 323-33, 1996.

Lima MC, Domingues MS, Cerqueira AT. Prevalence and risk factors of common mental disorders among medical students. Rev Saude Publica, 40: 1035-41, 2006.

Lima MS, Béria JU, Tomasi E, Conceição AT, Mari JJ. Stressful life events and minor psychiatric disorders: an estimate of the population attributable fraction in a Brazilian communitybased study. Int J Psychiatry Med, 26: 211-22, 1996.
Ludermir AB, Melo Filho DA. Living conditions and occupational organization associated with common mental disorders. Rev. Saúde Pública, 36: 213-21, 2002.

Mari JJ, Jorge MR. Transtornos psiquiátricos na clínica geral. Psychiatry On-line Brazil 1997; 2. http:// www.polbr.med.br/arquivo/tpqcm.htm (access in May 05, 2005).

Mari JJ, Williams PA. A validity study of a Psychiatric Screening Questionnaire (SRQ 20) in primary care in city of São Paulo. Br J Psychiatry, 148: 23-6, 1986.

Nascimento-Sobrinho CL, Carvalho FM, Bonfim TAS, Cirino CAS, Ferreira IS. Work conditions and mental health among doctors from Salvador, Bahia, Brazil. Cad Saúde Pública, 22 $131-40,2006$.

Nogueira-Martins LA, Fagnani-Neto R, Macedo PCM, Cítero VA, Mari JJ. The mental health of graduate students at the Federal University of São Paulo: a preliminary report. Braz J Med Biol Res, 37: 1519-24, 2004.

Pitta A. Hospital, dor e morte como ofício. São Paulo: Editora llucitec, 1990.

Polydoro SAJ, Primi R, Serpa MNF, Zaroni MMH, Pombal KCP. Desenvolvimento de uma escala de integração ao ensino superior. Psico-USF, 6: 11-7, 2001.

Rodrigues RND, Viegas CAA, Silva AAAA, Tavares P. Daytime sleepiness and academic performance in medical students. Arq Neuropsiquiatr, 60: 6-11, 2002.

Rosal MC, Ockene IS, Ockene JK, Barret SV, Ma Y, Hebert JR. A longitudinal study of students depression at one medical school. Acad Med, 72: 542-6, 1997.

Roth T, Roehrs TA. Etiologies and sequelae of excessive daytime sleepiness. Clin Ther, 18: 562-72, 1996

Saipanish R. Stress among medical students in a Thai medical school. Med Teacher, 25: 502-6, 2003.

Vaz RF, Mbajiorgu EF, Acuda SW. A preliminary study of stress levels among first year medical students at the University of Zimbabwe. Cent Afr J Med, 44: 214-9, 1998

Yiu V. Supporting the well-being of medical students. CMAJ, 172: 889-90, 2005. 